\title{
ВПЛИВ ВИСОКОШВИДКІСНИХ МАГІСТРАЛЕЙ НА ІНШІ ВИДИ ТРАНСПОРТУ В СУЧАСНИХ УМОВАХ
}

Канд. техн. наук С.М. Продащук, Ю.В. Биковська, С.С. Івахненко

\section{ВЛИЯНИЕ ВЫСОКОСКОРОСТНЫХ МАГИСТРАЛЕЙ НА ДРУГИЕ ВИДЫ ТРАНСПОРТА В СОВРЕМЕННЫХ УСЛОВИЯХ}

\author{
Канд. техн. наук С.Н. Продащук, Ю.В. Быковская, С.С. Івахненко
THE IMPACT OF HIGH-SPEED LINES FOR OTHER MODES OF TRANSPORT IN MODERN CONDITIONS

Cand. of tehn sciences S.M. Prodaschuk, master student Y.V.Bykovs'ka, S.S. Ivakhnenko

У даній роботі було описано чинники, щзо мають вплив на конкуренцію за ринок перевезення пасажсиів при впровадженні високошвидкісних магістралей (ВШМ) з іншими видами транспорту в Україні. Проведено огляд досвіду у світі з иього питання, виконано аналіз існуючих методів визначення дочільності введення додаткових маршрутів прискорених поїздів в Україні.

Ключові слова: високошвидкісні магістралі, швидкісні поїзди, транспортна мережа України, пасажсирооборот, конкуренція, мобільність населення.

В данной работе были описаны факторы, влияющие на конкуренцию рынка перевозки пассажсиров при внедрении высокоскоростных магистралей (ВСМ) с другими видами транспорта в Украине. Проведен обзор опыта в мире по этому вопросу, выполнен анализ существующих методов определения иелесообразности введения дополнительных маршрутов ускоренных поездов в Украине.

Ключевые слова: высокоскоростные магистрали, скоростные поезда, транспортная сеть Украины, пассажирооборот, конкуренция, мобильность населения.

In this paper we described the factors affecting the market competition carriage of passengers, the introduction of high-res with other modes of transport in Ukraine. Clarified the importance of implementation The review of the experience in the world on this issue, the analysis of existing methods for determining the appropriateness of additional routes express trains in Ukraine.

Keywords: high-speed highways, high-speed trains, the transport network of Ukraine, passenger traffic, competition, the growth of population mobility.

Вступ i постановка проблеми. Створення високошвидкісних магістралей в Україні $€$ одним 3 найважливіших напрямів розвитку залізниці [1]. Впровадження швидкісного та високошвидкісного руху дасть можливість підвищення рівня конкурентоспроможності залізничного транспорту, прискорення науково-технічного процесу та принципового покращення обслуговування пасажирів.

Важливим питанням у проекті ВШМ $є$ його вплив на роботу інших видів транспорту, при його вирішенні треба враховувати світовий досвід.

На сучасному етапі інтегрування України в Європу збільшення швидкості пасажирських поїздів $\epsilon$ актуальним напрямом розвитку залізниць, бо обслуговування пасажирів повинно відповідати європейському рівню сервісу. При розвитку мережі залізниць для швидкісного пасажирського сполучення необхідно враховувати цілий спектр різних чинників, таких як соціально-економічних, транспортно-логістичних. Для успішного функціонування ВШМ потрібно вивчити конкуренцію на ринку пасажирських перевезень і ввести в експлуатацію таку кількість швидкісних поїздів, щоб повністю задовольнити потреби пасажирів, і поєднати найбільші міста для розвитку ділових $\mathrm{i}$ культурного зв'язків усієї країни. 


\section{Експлуатація залізниць}

\begin{abstract}
Аналіз останніх досліджень i публікацій. Проблемами розвитку високошвидкісного залізничного транспорту займались С.С. Жабров, Е.А. Сотников [2], В.Ю. Козлов [3], А.В. Момот [4]. Дослідження щодо встановлення раціональної кількості швидкісних пасажирських поїздів і їхніх максимальних швидкостей за умови суміщеного руху вантажних i пасажирських поїздів було проведено в роботі В.Ю. Козлова. Це дуже актуально для сучасних умов українських залізниць, адже недостатне фінансування та досить великий обсяг роботи 3 реформування інфраструктури задля впровадження окремих ліній курсування швидкісних поїздів $\epsilon$ неможливим. А.В. Момот у своїх працях використовував методичний підхід до визначення раціональних швидкостей руху пасажирських поїздів і раціональних зон їх курсування. Але питання щодо визначення перспективної мобільності населення України, оптимальних зон курсування вказаних поїздів ще досконально не досліджено.
\end{abstract}

Мета статті. Аналіз світового досвіду впровадження ВШМ та взаємодії 3 іншими видами транспорту, дослідження введення нових сполучень швидкісними поїздами між великими містами України.

Основна частина. Україна має потужну транспортну мережу, до якої входять залізничний, автомобільний, річковий, морський, повітряний i трубопровідний транспорт. 22 лютого 2012 р. для організації швидкісного руху на теренах України було створено Українську залізничну швидкісну компанію. Це державне підприємство, яке підпорядковане Державній адміністрації залізничного транспорту України (Укрзалізниця). Мережа маршрутів Української залізничної швидкісної компанії має досить широкий спектр. Зараз вона об'єднує Київ 3 найбільшими промисловими центрами України: Запоріжжя, Дніпропетровськ, Харків, а також культурними центрами історичного регіону Галичини: Львовом i Тернополем, поєднує Трускавець та Одесу. Схема курсування швидкісних поїздів територією України наведена на рис. 1.

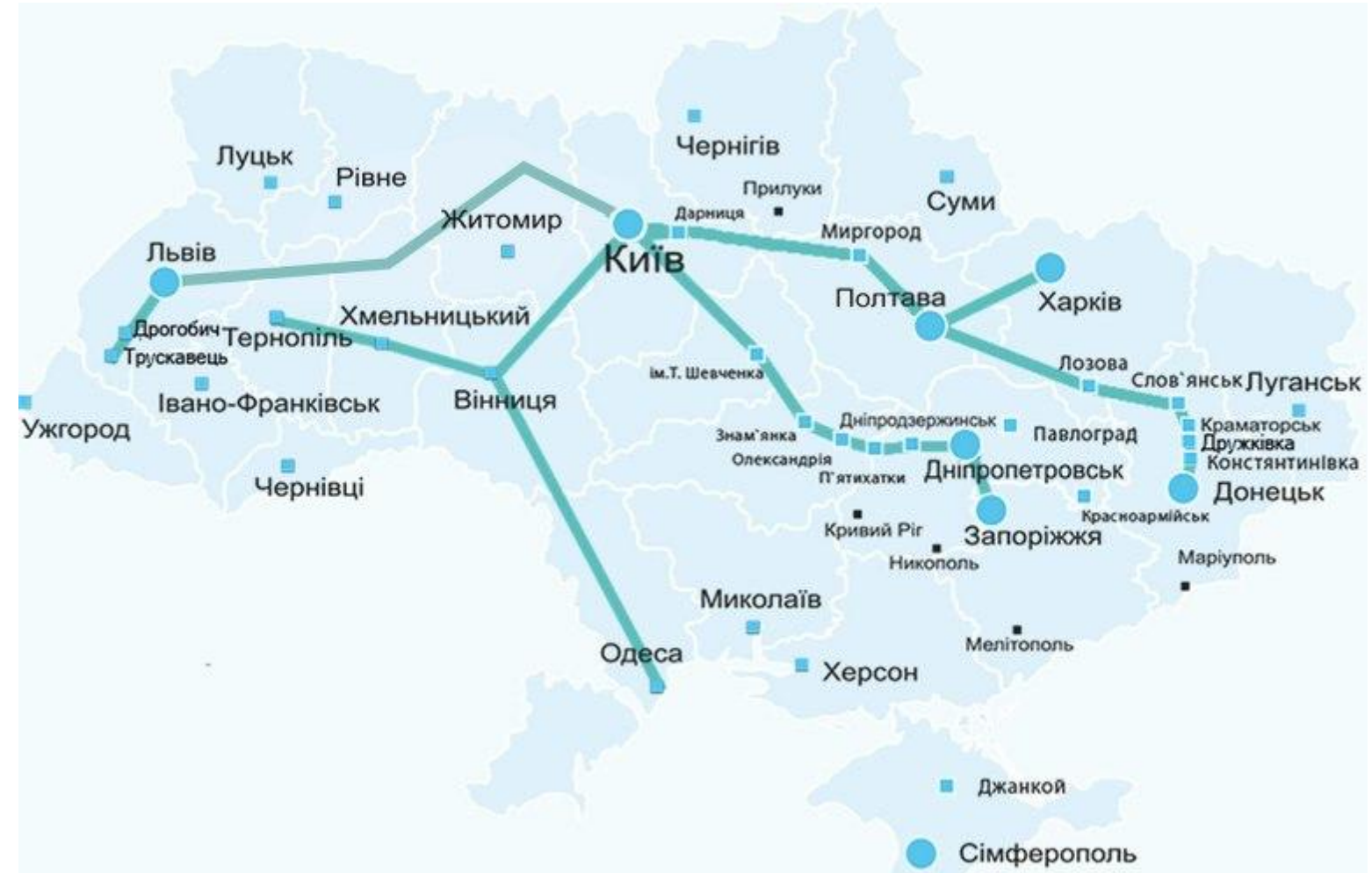

Рис. 1. Схема курсування швидкісних поїздів територією України 
Слід зазначити, що курс Української залізничної швидкісної компанії повністю узгоджується зі стратегією реформування галузі - сегментування залізничного транспорту за окремими напрямками діяльності. Українська залізнична швидкісна компанія створена 3 метою розширення та покращення комплексу послуг, що надаються пасажирам під час поїздки у швидкісних поїздах.

Українська залізнична швидкісна компанія на сьогодні експлуатує 12 пар швидкісних поїздів категорії Інтерсіті+ та Інтерсіті: 10 швидкісних електропоїздів Hyundai Rotem HRSC 2 i 2 швидкісні електропоїзди ЕКр-1 «Тарпан» виробництва ПрАТ «КВБЗ». Увесь рухомий склад компанії має робочі швидкості руху до 160 км/год [5].

За час існування компанії попит на залізничні перевезення швидкісними поїздами постійно підвищується. Наприклад, за період 3 початку 2015 року середня населеність у всіх поїздах Інтерсіті+ за чотири місяці сягнула $61 \%$, а у травні вона вже становила $68 \%$. Тоді як у цілому в 2014 р. цей показник становив $54 \%$.

Але існують перепони на шляху розвитку ВШМ в Україні. Внаслідок поганого стану інфраструктури існують обмеження, що стосуються швидкості для поїздів Інтерсіті+, часті відмови обладнання поїздів «Hyundai Rotem» через недостатню адаптацію до умов клімату загострюють конкурування основних видів транспорту, що перевозять пасажирів.

Дані про кількість перевезених пасажирів і пасажирооборот за 2014 рік [6] залізничним, автомобільним та авіаційним транспортом наведено в таблиці.

Статистичні дані пасажирських перевезень за 2014 р. у межах України

\begin{tabular}{|l|r|r|r|r|}
\hline \multirow{2}{*}{ Транспорт } & \multicolumn{2}{|c|}{ Пасажирооборот } & \multicolumn{2}{c|}{ Перевезено пасажирів } \\
\cline { 2 - 5 } & млн пас.км & \% до 2013 p. & млн & \% до 2013 p. \\
\hline залізничний & 35623,5 & 78,3 & 389,1 & 96,4 \\
\hline автомобільний & 42696,9 & 92,5 & 2915,3 & 91,2 \\
\hline авіаційний & 11583,7 & 95,1 & 6,5 & 83,2 \\
\hline
\end{tabular}

Аналізуючи пасажирооборот, можна зробити висновок, що автомобільний транспорт $\epsilon$ найбільшим конкурентом залізниць в Україні. Конкуренція залежить від вибору пасажира, який користується такими критеріями:

- комфорт під час поїздки;

- вартість квитка;

- зручність придбання квитка;

- час поїздки;

- відсутність пересадок.

Основними чинниками, що дають перевагу швидкісному залізничному руху перед автомобільним, $€$ поганий стан автошляхів, подорожчання пального і відповідно зростання цін на автобусні перевезення.

В авіаперевізників магістраль забере пасажиропотік, але цю частку сьогодні прогнозувати складно. На відстані 500-800 кілометрів пасажири роблять вибір між поїздом і літаком виходячи 3 міркувань комфорту, розкладу, ціни та особистих уподобань.
Аналіз ринку транспортних послуг за кордоном показує, що основним конкурентом високошвидкісних залізничних перевезень $\epsilon$ авіаційний транспорт.

Високошвидкісні залізничні сполучення відіграють домінуючу роль, якщо час поїздки не перевищує двох годин. Їх частка може досягати $85 \%$ i в тих випадках, коли час поїздки складає 2 год 30 хв, навіть якщо повітряний транспорт на відповідних маршрутах пропонує високу частоту рейсів літаків великої місткості. При часі поїздки, що становить 3 год, частка високошвидкісних залізничних сполучень утримується на рівні $60 \%$. Прикладом є міжнародні ВШМ зі сполученням Париж - Лондон, Париж - Бордо, Стокгольм - Гетеборг.

Залізниці в ряді випадків зберігають свої позиції на ринку i при часі поїздки, що перевищує 3 год. Їх частка становить $40-50 \%$ на маршрутах Париж - Амстердам, 20-30 \% на 
маршрутах Париж - Тулон, Париж - Тулуза (5 год); 10-20 \% на маршрутах 3 часом поїздки 6-6,5 год. Частка високошвидкісного транспорту на ринку пасажирських перевезень залежно від часу поїздки наведена на рис. 2. Визначено, що чим менший час подорожі, тим більше пасажирів обирають високошвидкісний залізничний рух.

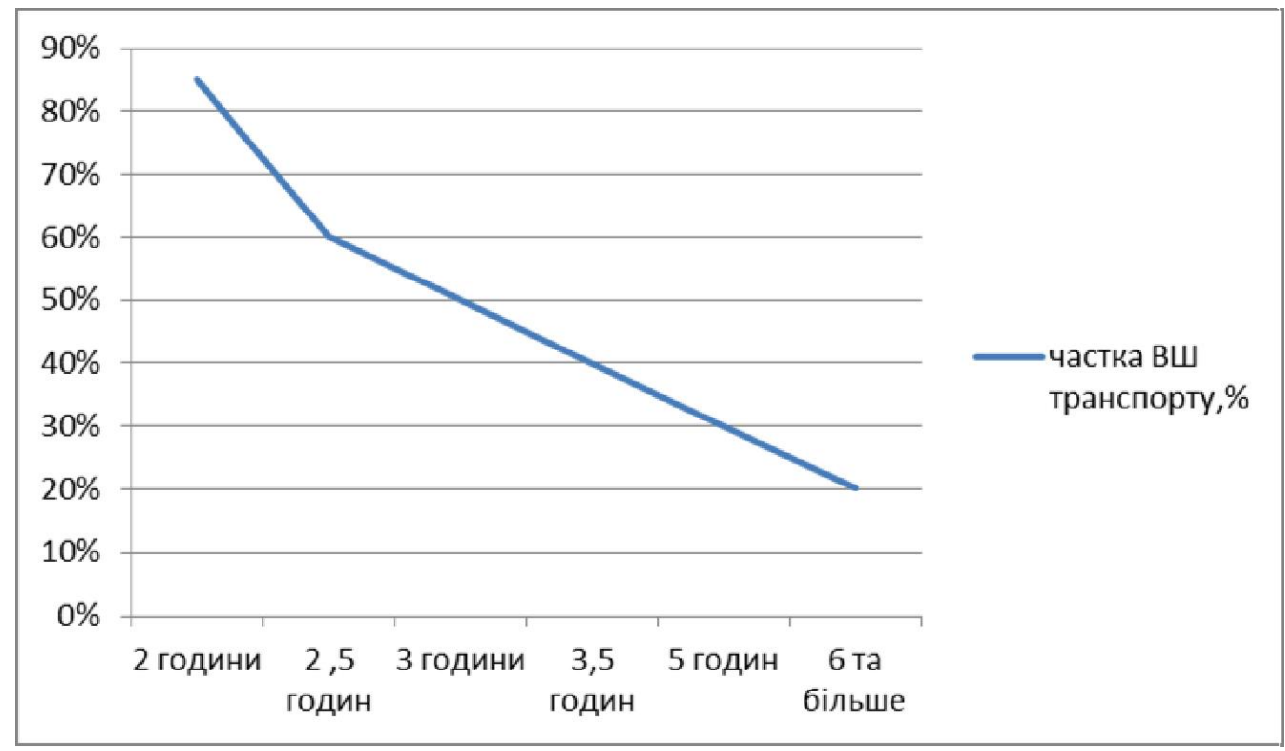

Рис. 2. Частка високошвидкісного транспорту на ринку пасажирських перевезень залежно від часу поїздки

Що стосується відстаней, то природною нішею повітряного транспорту залишаються сполучення на відстанях більше 1000 км. Тут авіаперевезення мають беззаперечну перевагу, навіть незважаючи на те, що деяку частину пасажиропотоків можуть взяти на себе нічні поїзди підвищеного рівня комфорту.

На відстанях у 500-1000 км має місце інтенсивна конкуренція між залізничним i повітряним транспортом, i вирішальну роль при виборі пасажирами одного з них відіграє скоріше не тривалість поїздки або польоту, а набір і якість додаткових послуг.

Світовий досвід показує, що високошвидкісний залізничний транспорт за швидкістю доставки пасажирів, економічністю та екологічною чистотою займає нішу перевезень на відстані 400-800 км. Використання повітряних суден на маршрутах такої дальності, як правило, економічно і 3 міркувань безпеки невигідно.

Покращення інфраструктури, сервісу та обслуговування пасажирів на існуючих сполученнях швидкісних поїздів України та розроблення нових маршрутів їх курсування зможе підвищити частку залізничного транспорту на ринку пасажирських перевезень. Доцільно було розробити додаткові сполучення між великими містами, наприклад Ужгород Запоріжжя. На сьогодні залізничний транспорт України не може запропонувати пасажирам поїзд, який би поєднав ці міста.

Для визначення доцільності введення нових сполучень необхідно враховувати ряд чинників:

- населеність міст;

- обсяги існуючих пасажирських перевезень;

- кількість високошвидкісних поїздів 3 урахуванням графіка ї руху та кількість проміжних зупинок;

- наявність ремонтних підрозділів (депо та заводи);

- вартість об'єктів інфраструктури високошвидкісного транспорту;

- ефективність або можлива збитковість перевезень пасажирів у напрямку, що реконструюється під високошвидкісний рух.

Обсяг перевезень по новому маршруту можна визначити за методикою розрахунку французької компанії SYSTRA [7]. Компанія 
пропонує виконувати розрахунок за допомогою формули

$$
\Pi_{\mathrm{AB}}=k \frac{H_{A} \cdot H_{B}}{f\left(L_{\mathrm{M}} \cdot T_{\mathrm{M}}\right)^{\prime}}
$$

де $\Pi_{\mathrm{AB}}-$ обсяг перевезень між двома кінцевими містами А і В, тис. люд;

$\mathrm{k}, \mathrm{f}$ - відповідно коефіцієнт моделі і частота поїздок;

$\mathrm{H}_{\mathrm{A}}, \mathrm{H}_{\mathrm{B}}-$ населення двох кінцевих міст відповідно А та В, тис. люд;

$L_{\mathrm{M}}-$ довжина маршруту, км;

$T_{\mathrm{M}}$ - час поїздки високошвидкісним поїздом по маршруту між місцями А та В, год.

Також для розрахунку перспективних перевезень використовується формула [4]

$$
\Pi_{\mathrm{AB}}=2 \frac{\left(H_{A}+T_{A}\right) \cdot\left(H_{B} \cdot T_{B}\right)}{\left(H_{\mathrm{BUM}} \cdot T_{\mathrm{EmM}}\right)} \cdot R \cdot K_{1} \cdot K_{\mathrm{ulac}}
$$

де $\Pi_{\mathrm{AR}}-$ прогнозна річна кількість перевезених пасажирів між двома містами А та В, тис. люд;

$H_{A}, H_{B}$ - населення міст відповідно А та В, тис чол.;

$T_{A}, T_{B}$ - транзитний пасажиропотік 3 країн СНД по станції А та у зворотному русі зі станції В, тис. люд;

$H_{\text {вщм }}$ - загальна кількість населення на всіх станціях високошвидкісної магістралі, тис. люд;

$T_{\text {вшм }}$ - транзитний пасажиропотік 3 країн СНД по всіх станціях високошвидкісної магістралі, тис. люд;

$\mathrm{R}$ - частка рухливості населення України по ВШМ;

$K_{1}-$ коефіцієнт, що враховує термін поїздки пасажирів на заданій ділянці;

$K_{\text {пас }}$ - коефіцієнт, що враховує додатково частоту поїздки пасажирів на заданій ділянці.
На основі аналізу наведених методик можна зробити висновок, що формула (1) $\epsilon$ менш ефективною, оскільки не враховується транзитний пасажиропотік, який доцільно перевести на швидкісне сполучення. Методика за формулою (2) дозволяє розподілити пасажирів по окремих дільницях $з$ урахуванням рухливості населення, враховує транзитний пасажиропотік, а це дуже важливо для умов географічного розташування України. Враховує особливості міст, що будуть поєднані швидкісними поїздами, і термін поїздок.

Висновки $з$ дослідження і перспективи, подальший розвиток у даному напрямку. Стрімкий розвиток ділових, культурних, економічних i туристичних зв'язків, викликаний розвитком інтеграційних процесів, $€$ постійно діючим чинником, що обумовлює зростання потреб у швидкісних пасажирських перевезеннях як у даний час, так i в перспективі. Враховуючи європейський досвід, основним завданням при введенні нових швидкісних ліній і магістралей для Української залізничної швидкісної компанії є визначення місткості ринку для всієї мережі або для поїздок між окремими пунктами. Щоб створені маршрути користувались попитом, необхідно розрахувати обсяг майбутніх перевезень, враховуючи багато чинників (рухливість населення, терміни поїздок, населення міст і їx особливості) і зіставити з загальним обсягом далеких пасажирських перевезень залізниць або 3 обсягами перевезень інших видів транспорту. При цьому для збільшення конкурентоспроможності 3 іншими видами транспорту необхідно визначити відстані подорожі, на яких швидкісний рух зможе отримати збільшення потоку пасажирів. Це $\epsilon$ можливим при застосуванні досвіду впровадження ВШМ у світі.

\section{Список використаних джерел}

1. Транспортна стратегія України на період до 2020 року [Електронний ресурс]: Розпорядження Кабінету Міністрів України від 20 жовтня 2010 р. № 2174. - Режим доступу: http://zakon.rada.gov.ua. Назва з екрана.

2. Жабров, С.С. Скоростной и высокоскоростной транспорт [Текст] / С.С. Жабров, Е.А. Сотников, В.И. Ковалев // Железнодорожный транспорт. - 1998. - №4. - С. 39-42.

3. Козлов, В.Ю. Обоснование экономически рационального числа скоростных пассажирских поездов [Текст] / В.Ю. Козлов // Труды МИИТ. - 1982. - Вып.715. - С. 90-94.

4. Момот, А.В. Методичний підхід до визначення раціональних швидкостей руху пасажирських поїздів та раціональних зон їх курсування [Текст] / А.В. Момот // Пробл. економіки трансп.: зб. наук. 


\title{
Експлуатація залізниць
}

пр. Дніпропетр. нац. ун-ту заліз. трансп. ім. акад. В. Лазаряна. - Дніпропетровськ, 2013. - Вип. 5. C. 80-89.

5. Українська залізнична швидкісна компанія [Електронний ресурс]. - Режим доступу: www/URL: http://www.intersity.uz.gov.ua.

6. Звітні дані Державної служби статистики України за 2014 рік [Електронний ресурс]. - Режим доступу: www/URL: http://www.ukrstat.gov.ua/.

7. Предварительное технико-экономическое обоснование проэкта высокоскоростных железных дорог в Украине «SYSTRA». - K., 2002. - 213 c.

Рецензент д-р техн. наук, професор О.М. Огар

\begin{abstract}
Продащук Світлана Миколаївна, канд. техн. наук, доцент кафедри управління вантажною і комерційною роботою Українського державного університету залізничного транспорту. Тел. (057)-730-10-26; e-mail: sp7728@mail.ru.

Биковська Юлія Вікторівна, магістрант ІППК. Тел (050) 59-78-965; e-mail:yuliya.bykovskaya @mail.ru. Івахненко Сергій Сергійович, магістрант ІППК. Тел (067) 52-70-435; e-mail: sergun-ivahnenko@ya.ru.

Prodaschuk Svitlana, Cand. of tehn sciences, associate Professor of the Office of freight and commercial work of the Ukrainian state University of railway transport. Tel. (057)-730-10-26 e-mail: sp7728@mail.ru.

Bykovska Yuliya, listener IPPK. e-mail: yuliya.bykovskaya @mail.ru.

Ivakhnenko Serhii, listener. Tel. (067) 52-70-435 e-mail : sergun-ivahnenko@ya.ru.
\end{abstract}

Наукова праця здана до друку 17.06.2015 року 